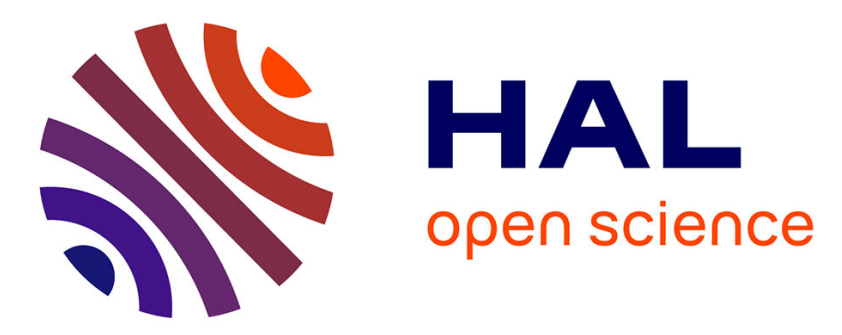

\title{
High oxidation state aqueous organometallics: synthesis and structure of a dinuclear oxo(pentamethylcyclopentadienyl)acetato complex of molybdenum(IV), [Cp*Mo $(\mu-\mathrm{O})(\mu-\mathrm{O} 2 \mathrm{CCH} 3)] 2$
}

Funda Demirhan, Philippe Richard, Rinaldo Poli

\section{To cite this version:}

Funda Demirhan, Philippe Richard, Rinaldo Poli. High oxidation state aqueous organometallics: synthesis and structure of a dinuclear oxo(pentamethylcyclopentadienyl)acetato complex of molybdenum(IV), $\left[\mathrm{Cp}^{*} \mathrm{Mo}(\mu-\mathrm{O})(\mu-\mathrm{O} 2 \mathrm{CCH} 3)\right] 2$. Inorganica Chimica Acta, 2003, 347, pp.61-66. 10.1016/S0020-1693(02)01439-1 . hal-03283678

\section{HAL Id: hal-03283678 \\ https://hal.science/hal-03283678}

Submitted on 19 Jul 2021

HAL is a multi-disciplinary open access archive for the deposit and dissemination of scientific research documents, whether they are published or not. The documents may come from teaching and research institutions in France or abroad, or from public or private research centers.
L'archive ouverte pluridisciplinaire $\mathbf{H A L}$, est destinée au dépôt et à la diffusion de documents scientifiques de niveau recherche, publiés ou non, émanant des établissements d'enseignement et de recherche français ou étrangers, des laboratoires publics ou privés. 
High oxidation state aqueous organometallics: synthesis and structure of a dinuclear oxo(pentamethylcyclopentadienyl)acetato complex of molybdenum(IV), $\left[\mathrm{Cp} * \mathrm{Mo}(\mu-\mathrm{O})\left(\mu-\mathrm{O}_{2} \mathrm{CCH}_{3}\right)\right]_{2}^{\dagger}$

\author{
Funda Demirhan, ${ }^{\S}$ Philippe Richard and Rinaldo Poli*
}

Laboratoire de Synthèse et d'Electrosynthèse Organométalliques (LSEO UMR 5632), Université de Bourgogne, Faculté de Sciences “Gabriel”, 6 boulevard Gabriel, 21000 Dijon, France.

Proofs to: Prof. Rinaldo Poli

Tel +33380396881

Fax +33380393720

E-mail: poli@u-bourgogne.fr

${ }^{\dagger}$ Dedicated to Rafael Uson in recognition of his contribution to inorganic chemistry

${ }^{\S}$ Permanent address: Celal Bayar University, Faculty of Sciences \& Liberal Arts, Department of Chemistry, 45030, Muradiye-Manisa, Turkey. 


\begin{abstract}
The zinc reduction of $\mathrm{Cp}^{*}{ }_{2} \mathrm{Mo}_{2} \mathrm{O}_{5}$ in a $\mathrm{MeOH}-\mathrm{H}_{2} \mathrm{O}$ mixture in the presence of acetic acid affords the diamagnetic dinuclear compound $\left[\mathrm{Cp} * \mathrm{MoO}\left(\mathrm{O}_{2} \mathrm{CCH}_{3}\right)\right]_{2}$. An X-ray structural investigation reveals a novel dioxo- and diacetato-bridged structure, with a relatively strong metal-metal bond $[2.5524(3) \AA]$. The compound exhibits a reversible one-electron oxidation process in the cyclic voltammogram. A comparison with other related structures reveals the effect of the electric charge on the mononuclear or dinuclear structural choice.
\end{abstract}

\title{
Keywords
}

Aqueous organometallic chemistry, molybdenum, half-sandwich complexes, metal-metal bonding, oxo ligands. 


\section{Introduction}

High oxidation state organometallic chemistry, in particular the chemistry of oxocyclopentadienyl compounds, has experienced a rapid development in the last 20 years. The earliest example is probably the molybdenum(VI) complex $\mathrm{Cp}_{2} \mathrm{Mo}_{2} \mathrm{O}_{5}$ [1]. More recently, halfsandwich oxo derivatives of rhenium have been extensively investigated [2-4] and found to possess a very rich chemical reactivity and catalytic activity. Although the oxo ligand is simply related to hydroxo and aquo ligands by two proton transfer steps - and indeed many organometallic oxo derivatives have first been obtained by the adventitious action of water on hydrolytically sensitive precursors - the chemistry of these materials in an aqueous environment has rarely been explored [5]. For metals having a rich electrochemical activity such as, for instance, molybdenum, it is possible to envisage new chemistry and electrochemistry in an aqueous environment, leading to potentially useful applications in catalysis and electrocatalysis.

Recently, we have initiated the investigation of the speciation and reductive electrochemistry of compound $\mathrm{Cp}_{2}{ }_{2} \mathrm{Mo}_{2} \mathrm{O}_{5}$ in a water-rich environment. First, we discovered [6] that the compound spontaneously ionizes in water to provide solutions of the previously unknown $\mathrm{Cp}^{*} \mathrm{MoO}_{2}{ }^{+}$cation together with the known $[7,8] \mathrm{Cp}^{*} \mathrm{MoO}_{3}{ }^{-}$anion. While the latter is the only species present at $\mathrm{pH}>6$, the former is generated essentially quantitatively at $\mathrm{pH}<1$. We have also shown the existence and the $\mathrm{pH}$-dependent stability of compound $\mathrm{Cp} * \mathrm{MoO}_{2}(\mathrm{OH})$. A subsequent reductive electrochemical investigation, with on-line detection of the reduction products by electrospray ionisation mass spectrometry (ESI-MS), has revealed the formation of a host of different mono-, di- and trinuclear products in oxidation states down to IV [9]. This investigation was carried out in a water-methanol solution, the $\mathrm{pH}$ being regulated at ca. 4 by use 
of an acetate buffer. In all cases, the $\left(\mathrm{Cp}^{*} \mathrm{Mo}\right)^{\mathrm{n}+}$ unit remains intact, namely there is no indication of acidolysis of the $\mathrm{Cp}^{*}$-Mo bond. This remarkable stability holds promise for the development of stoichiometric and catalytic transformations on the $\mathrm{Cp} * \mathrm{Mo}$ template in an aqueous environment.

Since most of the species that were identified during the electrochemistry/ESI-MS experiment are unknown, we were obviously interested in exploring the stoichiometric reduction chemistry with the hope of isolating one or more of these species. In this contribution, we report the zinc reduction of $\mathrm{Cp}^{*}{ }_{2} \mathrm{Mo}_{2} \mathrm{O}_{5}$ and the isolation and characterization of a novel dinuclear oxoacetato-bridged compound of Mo(IV).

\section{Experimental Section}

General procedures.

\section{Synthesis of Di- $\mu$-oxodi- $\mu$-acetatobis(pentamethylcylopentadienyl)dimolybden-}

um(IV), $\left[\mathbf{C p} * \mathbf{M o}(\boldsymbol{\mu}-\mathbf{O})\left(\boldsymbol{\mu}-\mathbf{O}_{2} \mathbf{C C H}_{3}\right)\right] 2$. To a solution of $\left[\left(\mathrm{Cp}^{*} \mathrm{Mo}_{2}\right)_{2} \mathrm{O}\right](0.15 \mathrm{~g}, 0.28 \mathrm{mmol})$ in $\mathrm{MeOH}: \mathrm{H}_{2} \mathrm{O}(1: 1,10 \mathrm{ml})$ were added metallic zinc $(1.5 \mathrm{~g}, 23 \mathrm{mmol})$ and 15 drops of glacial $\mathrm{CH}_{3} \mathrm{COOH}$. The mixture was stirred under argon at room temperature for 4 days during which time color changed while a precipitate formed, from yellow, through orange, red, and brown to finally yield a blue-green suspension. The solution was filtered and the solid was dried in vacuo for $2 \mathrm{~h}$. The product was treated with heptane $(5 \mathrm{ml})$ and the resulting suspension was heated to the reflux temperature and filtered hot to eliminate the excess metallic zinc and the other inorganic co-products. Slow cooling to room temperature afforded directly X-ray quality blue crystals of the title product $(0.025 \mathrm{~g}, 14.7 \%)$. Elem. Anal.: Calcd for $\mathrm{C}_{12} \mathrm{H}_{18} \mathrm{Mo}_{3}: \mathrm{C}, 47,07 ; \mathrm{H}$, $5.92 \%$. Found : C,45.99 ; H, $5.38 \% .{ }^{1} \mathrm{H}$ NMR $\left(\mathrm{C}_{6} \mathrm{D}_{6}\right): 1.98 \mathrm{ppm}\left(\mathrm{s}, 15 \mathrm{H}, \mathrm{C}_{5}\left(\mathrm{CH}_{3}\right)_{5}\right), 1.94 \mathrm{ppm}$ 
$\left(\mathrm{m}, 3 \mathrm{H}, \mathrm{CH}_{3} \mathrm{COO}\right)$. Cyclic voltammetry $(\mathrm{THF})$ : reversible 1-electron oxidation wave at $\mathrm{E}_{1 / 2}=-$ $0.498 \mathrm{~V}$ vs. ferrocene.

An identical experiment was carried out except that the reaction was stopped after $1 \mathrm{~d}$ of stirring. The red precipitate was filtered off, extracted into $\mathrm{CH}_{2} \mathrm{Cl}_{2}$ and the resulting solution was layered with heptane. The red crystals which formed were identified as $\mathrm{Cp}^{*}{ }_{2} \mathrm{Mo}_{2} \mathrm{O}_{4}$ by a unit cell determination (X-ray diffraction) and comparison with the literature [10].

Crystal structure determination. Crystal data and refinement figures are reported in table 1. The data set was collected on an Enraf-Nonius KappaCCD diffractometer at $110 \mathrm{~K}$ using Mo $\mathrm{K} \alpha$ radiation. The structure was solved via a Patterson search program [11] and refined with fullmatrix least-squares methods [12] based on $\left|\mathrm{F}^{2}\right|$ with the aid of the WINGX program [13]. All non-hydrogen atoms were refined with anisotropic thermal parameters. Hydrogen atoms were located on final Fourier difference maps and refined, after idealization, with a riding model with isotropic temperature factors fixed to 1.5 times those of the corresponding parent atoms.

\begin{tabular}{ll}
$\begin{array}{l}\text { Table 1. Crystal data and structure refinement for compound }[\mathrm{Cp} * \mathrm{Mo}(\mu- \\
\left.\mathrm{O})\left(\mu-\mathrm{O}_{2} \mathrm{CCH}_{3}\right)\right]_{2} \text {. }\end{array}$ \\
\hline Formula & $\mathrm{C}_{24} \mathrm{H}_{36} \mathrm{O}_{6} \mathrm{Mo}_{2}$ \\
$\mathrm{M}$ & 612.41 \\
$\mathrm{~T} ; \mathrm{K}$ & $110(2)$ \\
Crystal system & triclinic \\
Space group & $\mathrm{P}-1$ \\
$a ; \AA$ & $8.0864(1)$ \\
$b ; \AA$ & $11.9019(2)$ \\
$c ; \AA$ & $14.4101(3)$ \\
$\alpha{ }^{\circ}$ & $71.104(1)$ \\
$\beta ;{ }^{\circ}$ & $77.186(1)$ \\
$\gamma,{ }^{\circ}$ & $72.476(1)$ \\
$V ; \AA^{3}$ & $1239.32(4)$ \\
$Z$ & 2 \\
$\mathrm{~F}(000)$ & 624 \\
$D_{\text {calc }} ; \mathrm{g} / \mathrm{cm}^{3}$ & 1.641 \\
diffractometer & Enraf-Nonius KappaCCD \\
scan type & mixture of $\phi$ rotations and $\omega$ scans \\
$\lambda ; \AA$ & 0.71073 \\
$\mu ;$ mm & -1
\end{tabular}




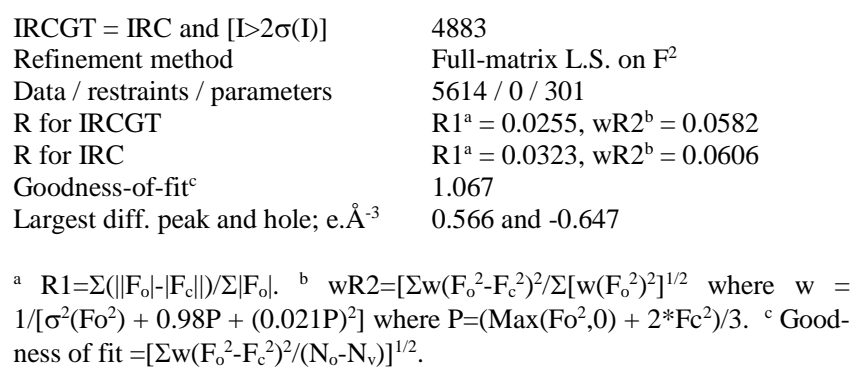

\section{Results}

The zinc reduction of compound $\mathrm{Cp}^{*}{ }_{2} \mathrm{Mo}_{2} \mathrm{O}_{5}$ in an acetic $1: 1(\mathrm{v} / \mathrm{v})$ water-methanol mixture ( $\mathrm{pH}$ ca. 4) takes place extremely slowly. During several days of stirring at room temperature, the mixture undergoes several color changes through orange, red, and brown to finally yield a blue-green suspension. In one instance the final precipitate was blue, but in all cases the pure blue product was recovered in small yields by recrystallization of the final blue or blue-green solid from hot heptane. No other product could be isolated from the reaction mixture, except for the previously known $\left[\mathrm{Cp}^{*} \mathrm{MoO}_{2}\right]_{2}$ when the reaction was stopped after 1 day of stirring. However, the variety of color changes suggests that other species are probably also present at intermediate times, in agreement with the complexity of the previously reported electrochemistry/ESI-MS study [9]. One of the observed products of this study was indeed the $\left[\mathrm{Cp} * \mathrm{MoO}_{2}\right]_{2}$ compound as its conjugate acid, $\left[\mathrm{Cp}^{*}{ }_{2} \mathrm{Mo}_{2} \mathrm{O}_{3}(\mathrm{OH})\right]^{+}$.

The X-ray structure of the isolated blue product (vide infra) indicates that it is a dinuclear compound of $\mathrm{Mo}(\mathrm{IV})$ with formula $\left[\mathrm{Cp} * \mathrm{Mo}(\mu-\mathrm{O})\left(\mu-\mathrm{O}_{2} \mathrm{CCH}_{3}\right)\right]_{2}$. Therefore, the redox process corresponds to the stoichiometry of equation 1 .

$$
\begin{aligned}
& \mathrm{Cp}^{*}{ }_{2} \mathrm{Mo}_{2} \mathrm{O}_{5}+2 \mathrm{Zn}+6 \mathrm{CH}_{3} \mathrm{COOH} \longrightarrow\left[\mathrm{Cp}^{*} \mathrm{Mo}(\mu-\mathrm{O})\left(\mu-\mathrm{O}_{2} \mathrm{CCH}_{3}\right)\right]_{2}+ \\
& 2 \mathrm{Zn}\left(\mathrm{O}_{2} \mathrm{CCH}_{3}\right)_{2}+3 \mathrm{H}_{2} \mathrm{O}
\end{aligned}
$$


The product is diamagnetic, as indicated by the ${ }^{1} \mathrm{H}$ NMR spectrum which shows two resonances in the expected ratio and with the expected chemical shifts for the $\mathrm{Cp}^{*}$ and $\mathrm{CH}_{3} \mathrm{CO}_{2}$ protons. A cyclic voltammetric investigation of the compound dissolved in THF shows a reversible one-electron oxidation process at $\mathrm{E}_{1 / 2}=-0.498 \mathrm{~V}$ vs. ferrocene. This is consistent with the relative stability of the oxidized product, the mixed-valence $\mathrm{Mo}_{2}(\mathrm{IV}, \mathrm{V})$ cation $\left[\mathrm{Cp}_{2}{ }_{2} \mathrm{Mo}_{2} \mathrm{O}_{2}\left(\mathrm{O}_{2} \mathrm{CCH}_{3}\right)_{2}\right]^{+}$, which corresponds in fact to one of the major products observed during the electrochemistry/ESI-MS study [9].

Table 2. Selected Bond lengths $[\mathrm{A}]$ and angles $[\mathrm{deg}]$ for $\left[\mathrm{Cp} * \mathrm{Mo}(\mu-\mathrm{O})\left(\mu-\mathrm{O}_{2} \mathrm{CCH}_{3}\right)\right]_{2}$.

\begin{tabular}{|c|c|c|c|c|c|}
\hline $\operatorname{Mo}(1)-\operatorname{Mo}(2)$ & $2.5524(3)$ & $\mathrm{O}(1)-\mathrm{Mo}(1)-\mathrm{O}(2)$ & $77.60(6)$ & $\mathrm{O}(1)-\mathrm{Mo}(2)-\mathrm{O}(2)$ & $77.91(6)$ \\
\hline CNT(1)-Mo(1) & $2.018(2)$ & $\mathrm{O}(1)-\mathrm{Mo}(1)-\mathrm{O}(5)$ & $82.43(6)$ & $\mathrm{O}(1)-\mathrm{Mo}(2)-\mathrm{O}(6)$ & $82.65(6)$ \\
\hline $\mathrm{Mo}(1)-\mathrm{O}(1)$ & $1.9412(14)$ & $\mathrm{O}(2)-\mathrm{Mo}(1)-\mathrm{O}(3)$ & $82.35(6)$ & $\mathrm{O}(2)-\mathrm{Mo}(2)-\mathrm{O}(4)$ & $83.20(6)$ \\
\hline $\mathrm{Mo}(1)-\mathrm{O}(2)$ & $1.9392(15)$ & $\mathrm{O}(3)-\mathrm{Mo}(1)-\mathrm{O}(5)$ & $79.77(6)$ & $\mathrm{O}(4)-\mathrm{Mo}(2)-\mathrm{O}(6)$ & $78.42(6)$ \\
\hline $\mathrm{Mo}(1)-\mathrm{O}(3)$ & $2.1592(14)$ & CNT(1)-Mo(1)-O(1) & $115.22(7)$ & $\mathrm{CNT}(2)-\mathrm{Mo}(2)-\mathrm{O}(1)$ & $115.34(7)$ \\
\hline $\mathrm{Mo}(1)-\mathrm{O}(5)$ & $2.1528(15)$ & $\mathrm{CNT}(1)-\mathrm{Mo}(1)-\mathrm{O}(2)$ & $115.46(7)$ & $\mathrm{CNT}(2)-\mathrm{Mo}(2)-\mathrm{O}(2)$ & $115.08(7)$ \\
\hline $\mathrm{O}(3)-\mathrm{C}(21)$ & $1.268(3)$ & $\mathrm{CNT}(1)-\mathrm{Mo}(1)-\mathrm{O}(3)$ & $112.69(7)$ & $\mathrm{CNT}(2)-\mathrm{Mo}(2)-\mathrm{O}(4)$ & $112.42(7)$ \\
\hline $\mathrm{O}(5)-\mathrm{C}(23)$ & $1.271(3)$ & CNT(1)-Mo(1)-O(5) & $112.31(7)$ & CNT(2)-Mo(2)-O(6) & $112.74(7)$ \\
\hline CNT(2)-Mo(2) & $2.022(2)$ & CNT(1)-Mo(1)-Mo(2) & $155.40(6)$ & $\mathrm{CNT}(2)-\mathrm{Mo}(2)-\mathrm{Mo}(1)$ & $155.50(6)$ \\
\hline $\mathrm{Mo}(2)-\mathrm{O}(1)$ & $1.9340(15)$ & $\mathrm{Mo}(1)-\mathrm{O}(1)-\mathrm{Mo}(2)$ & $82.39(6)$ & $\mathrm{Mo}(1)-\mathrm{O}(2)-\mathrm{Mo}(2)$ & $82.46(6)$ \\
\hline $\mathrm{Mo}(2)-\mathrm{O}(2)$ & $1.9335(15)$ & $\mathrm{C}(21)-\mathrm{O}(3)-\mathrm{Mo}(1)$ & $121.25(13)$ & $\mathrm{C}(21)-\mathrm{O}(4)-\mathrm{Mo}(2)$ & $120.59(14)$ \\
\hline $\mathrm{Mo}(2)-\mathrm{O}(4)$ & $2.1656(14)$ & $\mathrm{C}(23)-\mathrm{O}(5)-\mathrm{Mo}(1)$ & $121.27(14)$ & $\mathrm{C}(23)-\mathrm{O}(6)-\mathrm{Mo}(2)$ & $120.66(14)$ \\
\hline $\mathrm{Mo}(2)-\mathrm{O}(6)$ & $2.1682(15)$ & & & & \\
\hline $\mathrm{O}(4)-\mathrm{C}(21)$ & $1.267(3)$ & & & & \\
\hline $\mathrm{O}(6)-\mathrm{C}(23)$ & $1.268(3)$ & $\mathrm{CNT}(1)-\mathrm{Mo}(1)-\mathrm{Mo}(2)$ & $\mathrm{T}(2) \quad 0.9$ & & \\
\hline
\end{tabular}

A view of the molecular structure as determined by the single crystal X-ray analysis is shown in Figure 1. Selected bond distances and angles are listed in Table 2. The molecule occupies a general position in the asymmetric unit but possesses an approximate $\mathrm{C}_{2 \mathrm{v}}$ symmetry. It consists of a dinuclear metal-metal bonded (Mo-Mo $=2.5524(3) \AA$ ) tetrabridged structure, the four bridges consisting of two oxygen atoms and two acetato groups. The coordination geometry of each metal atom is completed by the symmetrically bonded $\left(\eta^{5}\right) \mathrm{Cp} *$ ring. 


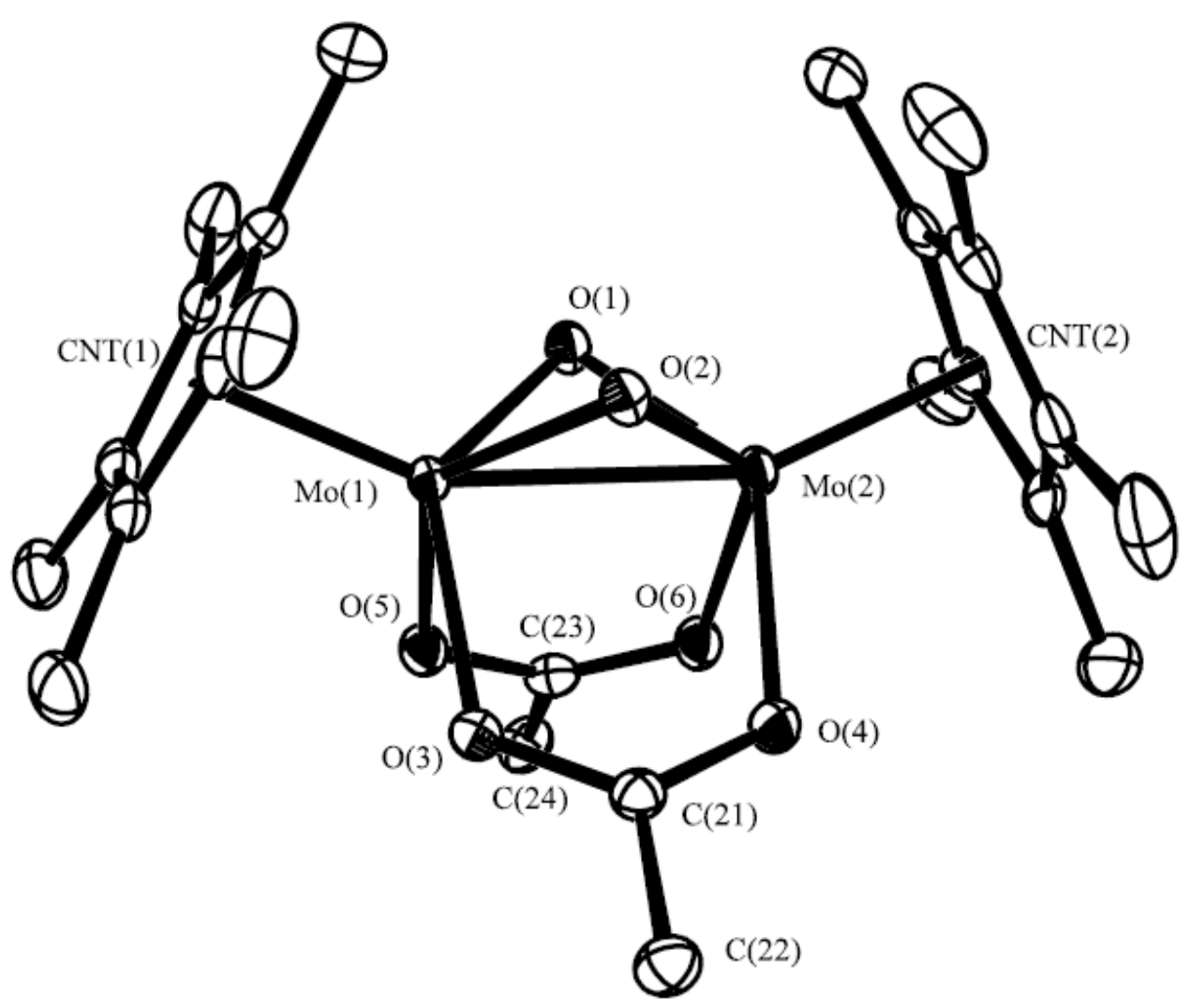

Fig. 1. An ORTEP view of compound $\left[\mathrm{Cp}^{*} \mathrm{Mo}(\mu-\mathrm{O})(\mu-\mathrm{O} 2 \mathrm{CCH} 3)\right] 2$. Ellipsoids are drawn at the $50 \%$ probability level.

This dinuclear structure is of a novel type for Mo. Related dinuclear $\mathrm{Cp}^{*} \mathrm{Mo}^{\mathrm{IV}}$ structures are those of the triply-bridged compounds $\left[\left(\mathrm{Cp}^{*} \mathrm{MoCl}\right)_{2}(\mu-\mathrm{Cl})\left(\mu-\mathrm{CO}_{3} \mathrm{H}\right)(\mu-\mathrm{O})\right]$ and $\left[\left(\mathrm{Cp}^{*} \mathrm{MoCl}\right)_{2}(\mu-\mathrm{Cl})_{2}(\mu-\mathrm{O})\right][14]$. The metal-metal distance in these compounds, which is 2.799(4) and 2.720(8) $\AA$, respectively, is significantly longer than that of the title compound. This difference can probably be attributed to the larger size of the bridging $\mathrm{Cl}$ atom in the previously reported examples and to the lone pair-lone pair repulsion between the terminal $\mathrm{Cl}$ ligands on different Mo atoms. A much greater number of dinuclear tetrabridged Mo(IV) compounds is known where one or more bridging groups is a sulfur atom. Examples (Mo-Mo distances in parentheses) are $\left[\mathrm{Cp}^{\prime} \mathrm{Mo}(\mathrm{S})(\mathrm{SMe})\right]_{2}(2.582 \AA)[15],\left[\left(\mathrm{Cp}^{\prime} \mathrm{Mo}\right)_{2}(\mathrm{~S})(\mathrm{SR})\left(\mathrm{S}_{2} \mathrm{CH}_{2}\right)\right]^{+}(\mathrm{R}$ 
$=\mathrm{Me}, 2.602(1)$ and 2.610(1) $\AA$ for two independent molecules; $\mathrm{R}=\mathrm{C}(\mathrm{Ph})=\mathrm{CH}_{2}, 2.613 \AA ; \mathrm{R}=$ $\mathrm{CH}=\mathrm{CHPh}, \quad 2.599(2)$ and 2.606(2) $\AA$ for two independent molecules) [16-18], $\left[(\mathrm{CpMo})_{2}(\mathrm{~S})_{2}\left(\mathrm{SPr}^{\mathrm{i}}\right)\left(\mathrm{PPh}_{2}\right)\right](2.623(2) \AA)[19]$, and $\left[(\mathrm{CpMo})_{2}(\mathrm{~S})(\mathrm{Te})(\mathrm{SPh})_{2}\right](2.6263(18) \AA$ [ [20]. The metal-metal distances in these examples compare much more favorably with that of the title compound, especially when allowance is made to the larger size of the bridging $\mathrm{S}$ atoms relative to oxygen.

The Mo-( $\mu$-O) distances (average 1.937(4) $\AA$ ) are significantly longer than those reported for the above mentioned $\left[\left(\mathrm{Cp}^{*} \mathrm{MoCl}\right)_{2}(\mu-\mathrm{Cl})\left(\mu-\mathrm{CO}_{3} \mathrm{H}\right)(\mu-\mathrm{O})\right]$ compound $(1.86(2) \AA)$ [14]. Analogous Mo- $\left(\mu_{2}-\mathrm{O}\right)$ distances in other compounds, even when the metal has a higher oxidation state, however, are comparable with those of the title compound provided the Mo- $\left(\mu_{2}-\mathrm{O}\right)-\mathrm{Mo}$ angle is sufficiently acute. Examples are $1.930(16) \AA$ (average) for $\mathrm{Cp}^{*}{ }_{4} \mathrm{Mos}_{5} \mathrm{O}_{11}$ [21], 1.967(9) $\AA$ (average) for $\left[\mathrm{Cp}^{*} \mathrm{Mo}_{6} \mathrm{O}_{18}\right]^{-}[14]$, and 1.952(9) $\AA$ (average) for $\mathrm{Cp}_{6}{ }_{6} \mathrm{Mo}_{8} \mathrm{O}_{16}$ [22]. The short metal-metal distance in the title compound forces rather acute Mo-( $\mu-\mathrm{O})$-Mo angles (average $\left.82.43(6)^{\circ}\right)$. The above mentioned hydrocarbonato complex [14] has a wider Mo-( $\mu$-O)-Mo angle, namely $97.6(12)^{\circ}$, allowing the possible greater intervention of Mo-O $\pi$ bonding. The Mo-O distances involving the acetato groups are longer and compare with those in the hydrocarbonato analogue, i.e. 2.12(2) $\mathrm{A}$.

\section{Discussion}

The aqueous reduction of $\mathrm{Cp}_{2}{ }_{2} \mathrm{Mo}_{2} \mathrm{O}_{5}$ represents a novel entry to middle-valent $\mathrm{Cp} *$ Mooxo compounds. A related reduction investigation, though in a non acqueous solvent $\left(\mathrm{CH}_{2} \mathrm{Cl}_{2}\right)$, is the cyclic voltammetry of the dinuclear $\mathrm{Mo}(\mathrm{V})$ compound $\left[(\mathrm{Cp} * \mathrm{MoOCl})_{2} \mathrm{O}\right]$ [23]. While a 
first one-electron reduction process is electrochemically reversible, the addition of the second electron yields an irreversible wave and the final Mo(IV) species could not be identified. By chemical reduction of either the same reagent or $\mathrm{Cp}^{*} \mathrm{MoOCl}_{2}$ with sodium in toluene or under other condition, Bottomley et al. isolated and structurally characterized the tetranuclear cluster $\mathrm{Cp}_{4}{ }_{4} \mathrm{Mo}_{4} \mathrm{O}_{7}$ [24]. A previous reductive study using zinc in THF, on the other hand, yielded a different product, described as $\left\{\left[\mathrm{Cp}^{*} \mathrm{MoCl}\right]_{4}(\mu-\mathrm{O})_{6}\right\}[\mathrm{ZnCl}(\mathrm{THF})]_{2}$, which could not be structurally characterized [25]. The dinuclear $\mathrm{Cp}^{*} \mathrm{Mo}^{\mathrm{IV}}$ complexes mentioned above were obtained by oxidative processes [14].
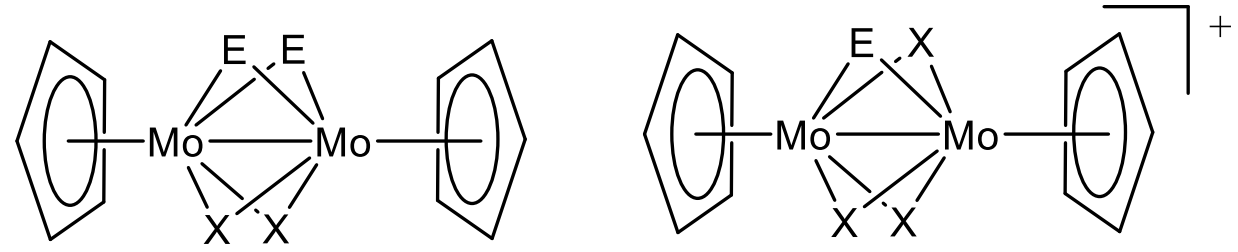

I

II
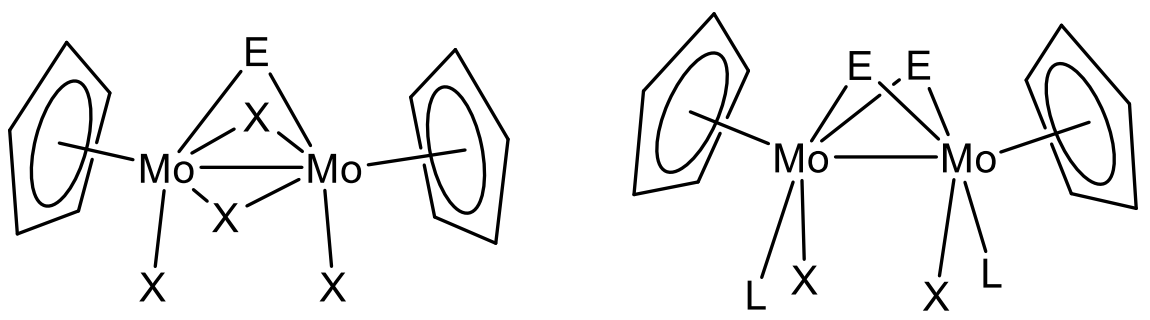

III

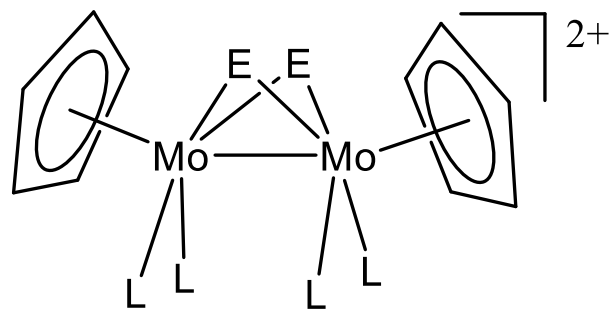

V

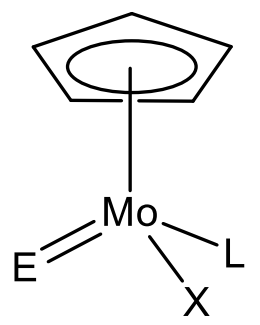

VI

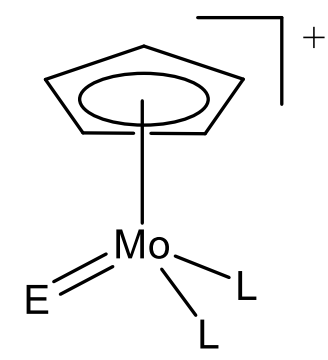

VII 
It is interesting to compare the structure of the title complex with that of other $\mathrm{CpMo} \mathrm{IV}^{\mathrm{IV}}$ complexes of similar stoichiometry. If we limit ourselves to molecules containing at least one divalent ligand $\mathrm{E}($ e.g. $\mathrm{O}, \mathrm{S}, \mathrm{Se}, \mathrm{Te})$, the various structures shown in I-VII are possible in principle $(\mathrm{X}=$ monovalent ligand with additional lone pair(s), $\mathrm{L}=$ neutral 2-electron donor). The tetrabridged structure $\mathbf{I}$ is exhibited by $[\mathrm{CpMo}(\mathrm{S})(\mathrm{SR})]_{2}$ type molecules [15] and isoelectronic analogues (e.g. $\mathrm{X}=\mathrm{PR}_{2}$ or $\left.\mathrm{E}=\mathrm{Se}, \mathrm{Te}\right)[19,20]$, while the related structure $\mathbf{I I}$ is found four a wide class of $\left[(\mathrm{CpMo})_{2}(\mathrm{~S})(\mathrm{SR})_{3}\right]^{+}$derivatives $[26,27]$. The tribridged structure III is shown by the above mentioned compound $\left[\left(\mathrm{Cp}^{*} \mathrm{MoCl}\right)_{2}(\mu-\mathrm{Cl})_{2}(\mu-\mathrm{O})\right][14]$. We are not aware of any precedent for dibridged structures of types IV and $\mathbf{V}$. The structure of the title compound can be related to type $\mathbf{I V}$, one $\mathrm{X}$ and one L ligand being replaced by the bidentate $\mathrm{O}-\mathrm{C}\left(\mathrm{CH}_{3}\right)=\mathrm{O}$ ligand. It is to be noted that each metal center in all these coordination geometries adopts a four-legged piano stool structure, allowing the two $\mathrm{d}^{2}$ metal center to establish two orbital interactions, one (strong) of type $\sigma$, the second (weak) of type $\delta$. The electronic structure in these types of molecules has been extensively analyzed before [28-30].

Even more interesting is the comparison between dinuclear and mononuclear structures. Structure VI is stoichiometrically identical to IV and could in principle be adopted by the title compound. Structure VII, on the other hand, is stoichiometrically identical to V. Compounds of type $\left[\mathrm{CpMoO}\left(\mathrm{PR}_{3}\right)_{2}\right]^{+}$adopt in fact the mononuclear structure rather than the dinuclear one, e.g. $\left[\mathrm{CpMoO}\left(\mathrm{PMe}_{3}\right)_{2}\right]^{+}[31]$. This change of structural preference may be associated to the charge difference, because a coulombic repulsion would destabilize the dinuclear structure $\mathbf{V}$. It is to be noted that the terminal $\mathrm{O}$ ligand in VII (and also in VI) is able to establish a $\sigma+2 \pi$ interaction, rendering the metal center electronically saturated. The positive charge in VII probably reinforces this interaction. 
The balance between the dinuclear and mononuclear structures is even more subtle. Our previous electrochemistry/ESI-MS experiment [9] has evidenced the formation and stability of the mononuclear cation $\left[\mathrm{Cp} * \mathrm{MoO}\left(\mathrm{O}_{2} \mathrm{CCH}_{3}\right)\right]^{+}$, where the metal has the formal oxidation state +5 , and the dinuclear cation $\left[\left(\mathrm{Cp}^{*} \mathrm{Mo}\right)_{2} \mathrm{O}_{2}\left(\mathrm{O}_{2} \mathrm{CCH}_{3}\right)_{2}\right]^{+}$, where the metal has an average formal oxidation state of +4.5 . The electrochemical investigation on the isolated title compound shows that the one-electron oxidation of $\left(\mathrm{Cp}^{*} \mathrm{Mo}\right)_{2} \mathrm{O}_{2}\left(\mathrm{O}_{2} \mathrm{CCH}_{3}\right)_{2}$ is reversible, confirming the stability of the dinuclear cation. Since the electron is lost from a $d_{x y}$-type orbital (engaged in the weak $\delta$ interaction), this cation should still enjoy a strong metal-metal interaction and the same should in principle be true for the product of a hypothetical second oxidation process. This process is not observed because it probably lies beyond the potential at which the solvent discharges. At any rate, the hypothetical dicationic dinuclear product should rearrange to the mononuclear isomer that has been observed by ESI-MS.

Thus, the $\mathrm{Mo}^{\mathrm{IV}}$ center still prefers to be associated to another metal center, so long as the molecule carried a single positive charge overall. It is to be remarked, however, that the strong $\pi$-donating ability of the oxo ligand could contribute to the stabilization of mononuclear structures such as VII. It is not excluded that a doubly charged dinuclear structure such as $\mathbf{V}$ may be adopted by complexes possessing weaker $\pi$-donating E ligands.

\section{Conclusion}

The synthetic strategy reported for the first time in the present contribution allows a simple access route to middle-valent cyclopentadienylmolybdenum compounds from a halidefree precursor. Therefore, the resulting $\left(\mathrm{Cp}^{*} \mathrm{Mo}\right)^{\mathrm{n}+}$ unit may be stabilized by an anionic ligand or 
counterion from a wide range of available acids. It will be interesting to explore the effect of the counterion, especially of its coordinating properties, on the nature, stability and reactivity of the reduction product(s). Initial studies by both electrochemical/ESI-MS and chemical reduction using the stronger trifluoroacetic acid show similarities but also important differences relative to the behavior in the presence of acetic acid. These studies have recently been communicated [32].

\section{Supplementary material}

Crystallographic data for the structural analysis have been deposited with the Cambridge Crystallographic Data Centre, CCDC No. CCDC 180477. Copies of this information may be obtained free of charge from The Director, CCDC, 12 Union Road, Cambridge, CB2 1EZ, UK (fax: +44-1223-336-033; e-mail: deposit@ ccdc.cam.ac.uk or ww: http://www.ccdc.cam.ac.uk).

Acknowledgement. We thank the French Ministery of Research and the CNRS for general funding through UMR 5632, and Mr. B. Rebière for technical assistance. FD is grateful to TUBITAK-NATO for a travel grant.

\section{References}

1 M. Cousins and M. L. H. Green, J. Chem. Soc. (1964) 1567-1572.

2 W. A. Herrmann, Comments Inorg. Chem. 7 (1988) 73-107. 
3 W. A. Herrmann, Angew. Chem., Int. Ed. Engl. 27 (1988) 1297-1313.

$4 \quad$ W. A. Herrmann and F. E. Kühn, Acc. Chem. Res. 30 (1997) 169-180.

5 O. Guzyr, J. Prust, H. W. Roesky, C. Lehmann, M. Teichert and F. Cimpoesu, Organometallics 19 (2000) 1549-1555.

6 E. Collange, J. Garcia and R. Poli, New J. Chem., in press.

7 M. S. Rau, C. M. Kretz, L. A. Mercando, G. L. Geoffroy and A. L. Rheingold, J. Am. Chem. Soc. 113 (1991) 7420-7421.

8 M. S. Rau, C. M. Kretz, G. L. Geoffroy and A. L. Rheingold, Organometallics 12 (1993) 3447-3460.

9 J. Gun, A. Modestov, O. Lev, D. Saurenz, M. Vorotyntsev and R. Poli, submitted for publication.

10 H. Arzoumanian, A. Baldy, M. Pierrot and M. Petrignani, J. Organometal. Chem. 294 (1985) 327-331.

11 G. M. Sheldrick, 'SHELXS97. Program for Crystal Structure solution', University of Göttingen, 1997.

12 G. M. Sheldrick, 'SHELXL97. Program for Crystal Structure refinement', University of Göttingen, 1997.

13 L. J. Farrugia, J. Appl. Crystallogr. 32 (1999) 837-838.

14 F. Bottomley and J. Chen, Organometallics 11 (1992) 3404-3411.

15 M. Rakowski DuBois, M. C. VanDerveer, D. L. DuBois, R. C. Haltiwanger and W. K. Miller, J. Am. Chem. Soc. 102 (1980) 7456-7461.

16 C. J. Casewit, R. C. Haltiwanger, J. Noordik and M. Rakowski DuBois, Organometallics 4 (1985) 119-129. 
17 J. C. V. Laurie, L. Duncan, R. C. Haltiwanger, R. T. Weberg and M. Rakowski DuBois, J. Am. Chem. Soc. 108 (1986) 6234-6241.

18 R. T. Weberg, R. C. Haltiwanger, J. C. V. Laurie and M. Rakowski DuBois, J. Am. Chem. Soc. 108 (1986) 6242-6250.

19 H. Adams, N. A. Bailey, A. P. Bisson and M. J. Morris, J. Organomet. Chem. 444 (1993) C34-C36.

20 P. Mathur, S. Ghose, R. Trivedi, M. Gelinsky, M. Rombach, H. Vahrenkamp, S. Banerjee, R. Philip and G. R. Kumar, J. Organometal. Chem. 595 (2000) 140-144.

21 F. Bottomley, J. Chen, K. F. Preston and R. C. Thompson, J. Am. Chem. Soc. 116 (1994) 7989-7995.

22 J. R. Harper and A. L. Rheingold, J. Am. Chem. Soc. 112 (1990) 4037-4038.

23 K. Umakoshi and K. Isobe, J. Organometal. Chem. 395 (1990) 47-53.

24 F. Bottomley, V. Sanchez, R. C. Thompson, O. O. Womiloju and Z. Q. Xu, Can. J. Chem. 78 (2000) 383-394.

25 F. Bottomley, E. C. Ferris and P. S. White, Organometallics 9 (1990) 1166-1171.

26 M. Rakowski DuBois, Chem. Rev. 89 (1989) 1-9.

27 M. Rakowski DuBois, Polyhedron 16 (1997) 3089-3098.

28 B. E. Bursten and R. H. Cayton, Inorg. Chem. 28 (1989) 2846-2853.

29 J. C. Green, M. L. H. Green, P. Mountford and M. J. Parkington, J. Chem. Soc., Dalton Trans. (1990) 3407-3418.

30 F. Abugideiri, J. C. Fettinger and R. Poli, Inorg. Chim. Acta 229 (1995) 445-454.

31 J. C. Fettinger, H.-B. Kraatz, R. Poli and E. A. Quadrelli, J. Chem. Soc., Dalton Trans. (1999) 497-508. 
32 F. Demirhan, J. Gun, O. Lev, A. Modestov, R. Poli and P. Richard, J. Chem. Soc, Dalton Trans. (2002) 2109-2111. 